\title{
有機太陽電 池
}

南信 次

\section{1.はじめに}

有機物䓄貝に適当な桑件下で光を照射すると電压や電流 が生ずることは，かなり以前から知られており，乙の現

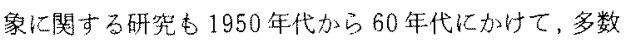
報告されている゙。しかし，てれ在太陽電池八応用する ことが䘳討さ㧈始めたのは，比較的最近のととである。 との背景として，二つの流机稀えられる。一つは，新

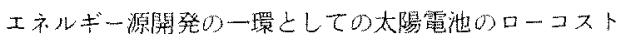
化という要請である。有機材料は一旦大量生産のライン に乗れば，加らり安伍に提供できるととが期待される。

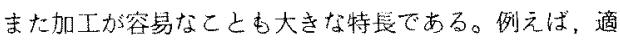
当な溶媒に溶加してキャストするととにより，此較的容 易に，均一で大きな膜を作ることができる。これは，太 陽笔池の大画樍化しいうニーズとも合致する。この上う

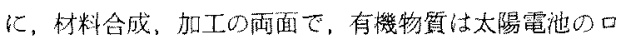
一コスト化に智与できる可能性を持っている。

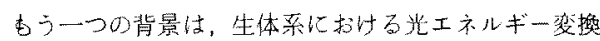
の仕組みを学び，てれをシミュレートするととによって 新しい人工的な太陽エホルギー变挺系を剧造しようとい う流れである。よく知られているように，植物の光合成 系に执てて，クロロフィルや $\beta$ 一カロチンなどの色素 分子が特買な集合状態を形成して括り，てれにプラスト

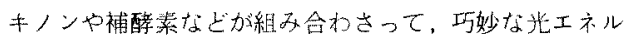
ギ一姿換工場加作動している。Cのうち，光工ネル゙ー

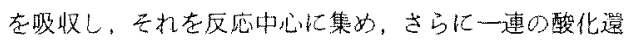
元反応，つまり電子の流机を引起ししていく過程は， 一㮔の光霓池とみなすとができる。この発想に基つい て㮔々のタイプの光電池加提案されている。例えば，梢 料ししてクロロフィル，ポルフィリン、フタロシアニン などを用いたり，電着法。照䖽法に上る配问脱を利用古 ることなどが辀みられている。

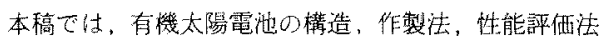

\section{Organic Solar Cells}

NOBUTSUGU MINAMI

Research Institute for Polymers and Textiles 工美技術院瀻維高分子材料研究所 主任研究官
を説明し，更に原理的な面之幾つかの赛例儿音及する。 比較的包括的なレビューが最近出されているのです。こ こでは主として, 前半の寒際的な面に重点を真く。

\section{2. 有機太陽電池の概要}

\section{1 構造と作り方}

有機太陽電池の一般的構造を図 1 に示す。これまでに 報告されているほとんよ゙のあのが、このように2種の電 極間比有機薄膜をサンドイッチした棒造老持つ。材料之 しては，天然あるいは合成の有機色素やポリア七チレン などの高分子が用いられる。乙机らの物質は可視城に求 ける吸光係数が大きく、1 $\mathrm{m}$ 以下の薄い膜で太陽光の 大部分を吸収することができる。

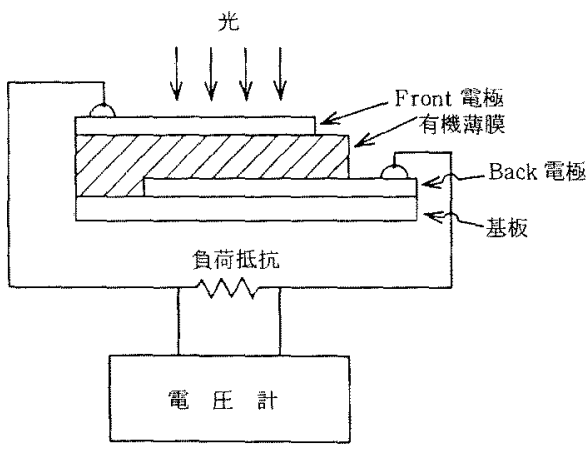

図 1 有機太陽電池の構造

薄膜作製法ししては，従来真空蒸着法加広く用いられ てきた。これは，金属や無機半導体で用いられているも のと，原理的に同しであって，有機物を真空中で加熱蒸 発させ，基板上付着させる万法である。注意す心゙さこ とは、材料が熱分解をおこさないよう蒸発源の温度制御 に気を配る点である。蒸発源としては，タングステンな ど茼融点金属のボートや，アルミナるつばなどが用いら れる。との方法は蒸発前に熱分解をおこすような物質に は適用できない。

あう一つは，溶液加らのキャスト法であり，高分子ゃ 
易溶性色素に適用されている。材料が不溶性のも00場 合には，啇当な高分子ハヘインダーの中に微粒子状化分散 して用いることができる。後者の手法は、従来、笔子写 真感比体の製造に用いられてきたものであるが，カナダ のXerox 社のグループの明究に上り，太陽電池用として も有望であるこしが明らかにされだ、゙。との方法は， 筫空装置が不要で色素の熱分解の恐扎もないなど，簡便 で有機物に適したものである。薄膜化に際しては、スピ ンナー doctor blade法などが用いられる。

これら以外に，電蓞法肪クロロフィル"界面活性フタ ロシアニン゙などに適用された。これは有機物の溶液に 電場をかけ，電気泳動に上って基板上に薄膜を付着さ甘

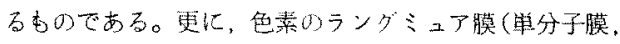

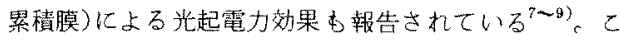
れらの方法は，膜の配向性が制御できるという点に特長 がある。このととは，初めに述べたような生体采のシ ニレーションという観点加らも眮味梁く、今後の進屡が 期待される薄膜化技術である。

四1で，必の入射する側の電栖( front 電極)には、 $\mathrm{Al}, \mathrm{In}, \mathrm{Cr}, \mathrm{ZnO}, \mathrm{CdS}$ な゙金属あるいは無機半導体の 半透明膜が用いら扎る。後述するように，多くの有機物 とこれらの電極の界洎近くには，電位勾配が形成されて おり，このととが有機物の光起電力效果発琴に重要な役 制を果たしている。反対側の)電極(back電極)には，こ のような電位勾配を作らないような材料，例えば、 $\mathrm{Ag}$ ， $\mathrm{Au} ， \mathrm{SnO}_{2} ， \mathrm{In}_{2} \mathrm{O}_{3}$ などが用いられる。電極の作製には， 蒸着法、スパッター法, 電着法などが用いられている。

\section{2 一般的特性}

图10ように两笔極間に負荷抵抗 $\left(R_{\mathrm{L}}\right)$ をつなぎ，光 照射すると，電圧計の針加ふれるのが観測される。その 極性ばほとんどの場合, front 電極側がマイナスよなる 万向である。電圧值 $(V) を R_{\mathrm{L}}$ で割って光電流值 $(J)$ が 求まる。 $R_{\mathrm{L}}$ の大ささ在色々変えながら測定在行ない。 横軸にV，綎朝にJをプロットすることにより，図2に 示す上うな北電流電生曲線が得られる。 $R_{\mathrm{L}}$ が電池の内

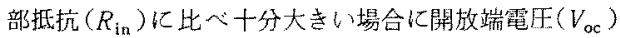
Łなり，逆比十分小さい場合に，短絡光電流 $\left(J_{\mathrm{sc}}\right)$ しな る。最大の電力 $\left(P_{\max }\right)$ が得られるのは、V×Jが最大と ふる時であり，図20斜線部がてれに相当する。エネル ギー变換効辣 $(\eta)$ は次式で与えられる。

$$
\eta=\frac{P_{\max }}{P_{\text {in }}} \times 100=\frac{V_{\mathrm{oc}} \times J_{\mathrm{sc}} \times F F}{P_{\mathrm{in}}} \times 100
$$

ここで，FFは， $V_{\text {oc }} \times J_{\text {sc }}$ に対する $P_{\text {max }}$ の比であり，fill factor（曲線因子）と呼枝れる。 $P_{\text {in }}$ は八射光のエネルギ 一であり，較正された熱電対やシリコンフォトセルなど て測定する。

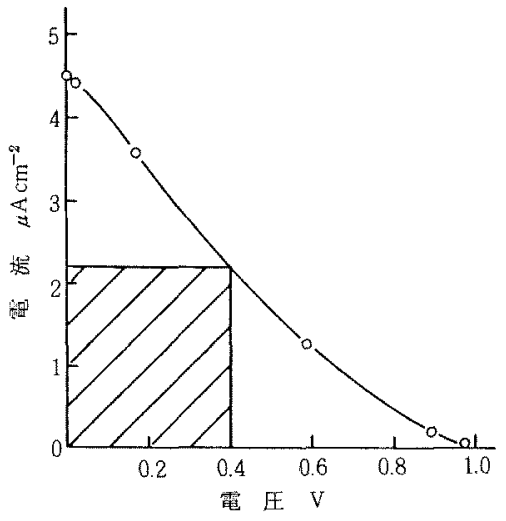

図 2 光電流電圧特性

$V_{o c}=0.98 \mathrm{~V}, J_{\mathrm{sc}}=4.5 \mu \mathrm{A} \mathrm{cm}^{-2} . F F=0.2$,
$\eta=2.2 \%, P_{\mathrm{in}}=40 \mu \mathrm{W} \mathrm{cm}^{-2}$

太陽電池の性能評洒は，当然太陽光下(あるいは模擬 太陽光下)で行なうべきものであるが，有機太陽電池の 舞合には，各研究每にまちまち0测定条件が採用されて いる。特に数マイクロワットという微弱光がしばしば用 いられるのは，強い光に対して速やかな経時为化交おて す場合があり，正確な性能評洒がやりにくいためでああ る。徉って，各種の有機太陽電池の性能を比較する場合 には，用いた入射光の種類 (白色光，単色光) と強度に注 意在払う必要がある。一般に有機物の場合には，光が強

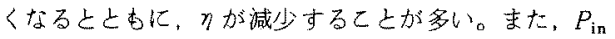
上して front 電極上の入射光强度を用いるか，それとあ front 電極を透過して有機薄膜上に入射したものを用い るかによりクの值加買なる。奏用上は当然前者を䓪準之

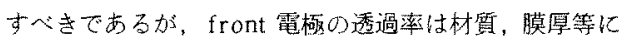
より異なるものであり，それらは性能評価上本質的でな い場合が多い。従って，各報告傎の比較する場合，現 时点では，後者を基準しした方が都合が良い。

励起光波長变えながら光電流を剆定することにより， 図 30 ような光電流スペクトルが得られる。その形状は， 用いた材料の吸取スペクトルに密接に関連している。す

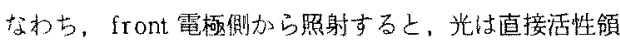
域に到達するので，吸収に対応した形となるのに対し， back 電極側然射では, 光が活性領域に到達するまでに 色素バルク層によって吸取されるため，透過スペクトル に類似した形状在示す。このように，照射方向变えて， 北電流のスペクトル特性在測ることにより，光活性部位 を知るこよがでる。 


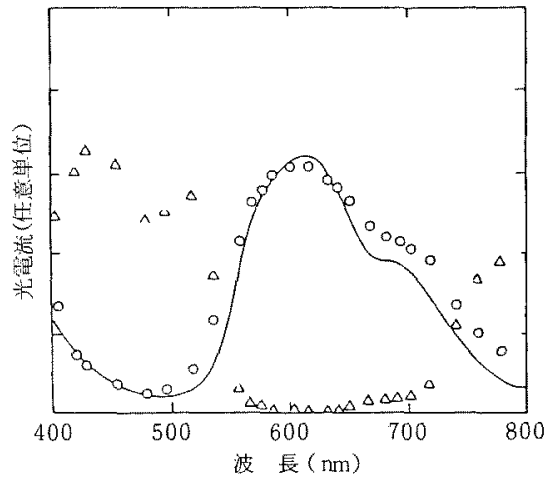

図 $3 \mathrm{In}_{2} \mathrm{O}_{3} /$ フタロシアニン分散膜 $/ \mathrm{Al}$ 光電池の 光笔流スペタトル ${ }^{10)}$

$\mathrm{Al}$ 側加ら光照射 $(\mathrm{O}) ， \mathrm{In}_{2} \mathrm{O}_{3}$ 側加占光照射 $(\Delta)$, 眼收スペクトル(一)

\section{3 湿式太陽電池}

図 10 front 電極を，電解筫溶液飞置きかえたものか， 湿式の太陽電池である。原理的には，乙れまで述へてき た乾式の6のと共通する点加多いが，湿式系に特有の実 験技術，すな⿰力口電気化学的な手法が幾つか用いられる。 この分野では従来，本多一藤嶋効果 ${ }^{11)}$ に代表される上う な，無機半導体電極の光電気化学的研究が主流であった。 有機色菜は，半導体電極の感度域を長波長側へ伸ばすた かの分光堌感剂として用いられることが多かった ${ }^{12)} \mathrm{c}$ 加し最近になって，有機固体薄膜自身を光応答性の電極 しして用いる研究が散見されるようになっている。

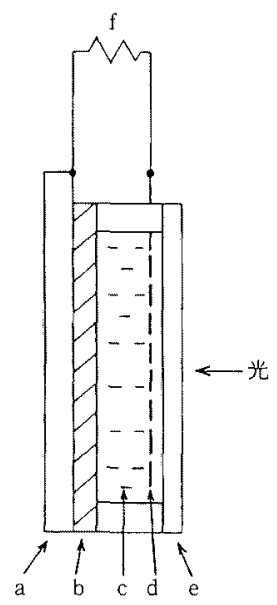

図 4 湿式有機太陽電池の满造

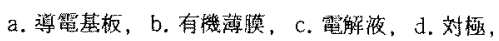
e. 密，f，負荷抵抗
その構造老，図4 亿模式的に示した。適当な導電基板 上に色素薄膜を作り，それを電解兵溶液之接触させる。 溶液中に白金板などを浸し，対電極として用いる。との 上うな系では，色素と溶液界面近傍に活性領域があり， 多くの場合，光妍起された色素加ら溶液側八電子か移動 することにより光電㐫答が生ずる。そのため，溶液中に， 酸素やキノン化合物などの電子受容性物質在添加するこ とに上り応答加增大する。

测定は乾式系の場合と同様である。但し，湿式系では， 色素電極と溶液との電位関係が，重要なパラターター上 なろので，適当な参照電極（銀熄化銀電極，飽和力口メ 儿電極などうに対して電住在測定したり，制御したりす るととが行なわれる。

\section{3. 原理}

図 5 は，光エネルギーが電気エネルギーに変換される プロセスを模式的に描いたものである。まず光を匢収し て，分子の励起状態が生ずる。これは高いエネルギー準 位に上げられた電子とそれが抜けた後に残された，正の 電荷を持つホールから成り，静電引力で互いに束縛され ている。とのぺアーは一種の䊀子あるい法波動(つまり 励起子)上して固体中動き回るととができる（励起分子 そのあのが動く訳ではなく励起状態が各分子間老飛び移 っていく〉。電子よホールが空閯的に同じ位置に留まる 限り，正負打ち消しあって正味の電気の流れは生じ得な い。そこで電荷の分離が乩てる必要がある。有機周体中 には，不可避的比構造的欠陥や，酸素など異種分子が含 まれており，電荷分離はその上うな場所で扔こると考え られている。例えば，励起色素から，酸菜など電子受容 性行子に電子が移動して，電何移動錯体が形成されるて とにより䉓荷分離が㕲こる。これが，有機半導体上無機 半導体で、大きく黑なる点である。後者では、バンド間

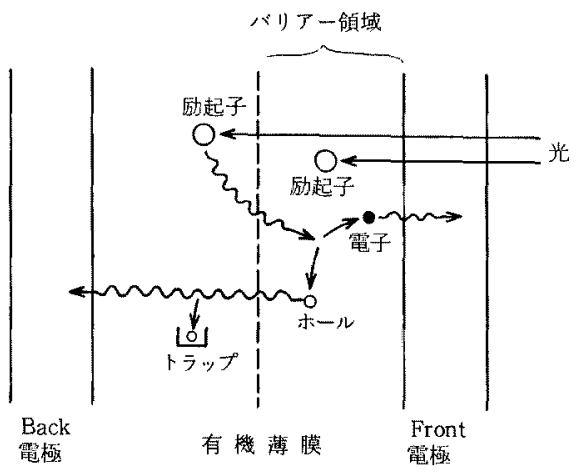

因 5 有機太陽電池におりる光電変換の原理図 
光吸取により，互いに束縛されない電子とホールが直接 生成する。

電荷分離が, front 電極よの界面近搒で招しった場命, そこに形成されている電位勾眍によって，正負の電荷は それぞれ逆方向に引つばられる。このようにして正味の 電気の流れが生ずる。Al，Inなどを front 電極に用い た系では，電子は front 極側へ，ホール他素バルク層 を横切って back電極側入上移動する。

色素上front 党極界面汇形成さ机る電位勾配は，半導

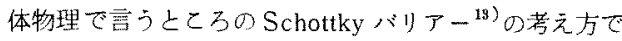
一応説明できる。 $\mathrm{Al}$ ，Inなど仕事関数の小さい金属の フェルミ準位は，色素のそれよりる高い位㯰にあるため， この両者を接触させると，金属加ら色素へ電子が流れこ みこれらは表面近傍に空間電荷に基つく笔位幻配を形 成する。外部回路が短絡状態にある時は、乙の電位勾配 内で生じたキャリア（纷離した電子やホール）は、次々に 外部へ流れ出てゆく。一力，回路が開いている時は， front 極周讱に電子が，反対側にホールが蓄皘し，内部 の電位勾配を打ち消すような万向に電場加形成されてい く。これが外から観測される $V_{o c}$ である。しかし，最近 の報告では，有機物/金属界面の挙動学純なSchottky バリアーモデルで説明するととに疑問が持たれている ${ }^{14,15) 。 ~}$ との点、命後の研究の進展が待たれる。

以上述べたそれぞれのプロセスに付随して，エネルギ 一のロスが执しり得る。励起状態の移動中には，輻射的 あるいは熱的な電子ーホールの再結合が扰こる。電何移動 状態やキャリアになってからも再結合は㧍こり得る。特 にキャリアに対するトラップが再結合中心になると考え られている ${ }^{16)}$ 。エネルギー变換效速を问上させるために は，ての上うな阻害要因を究明し，解消していか格ばな らない。例艺ば，電子受容性物質を意図的に混ぜてやる (ドーピング)ことによって電荷分離を促進し，励起状態 の再結台を抑制するととができる。またトラップの数を 減らして、キャリアを動き易くするととも重要である。

\section{4. 有機太陽電池の塞例}

これまでに報告されている乾式及び湿式の有機太䏂電 池の代表例を，それぞれ表 1 及び表 2 に揭げる。光照射 の条件むわかる範囲で示した。

このうちメロシアニンは，有機物ししてはじめて太陽 光評価で $1 \%$ 近いエネルギ一変換效率を達成したもの上

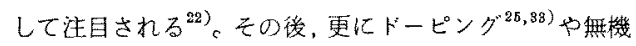
半導体とのへテロ接合方式 ${ }^{26)}$ などの夫が括てなわれて いるが, 今のところ最初のExxonグループのデータを淩 嘿する報告はない上うである。一方で，分子構造を系統 的に改変した時の影整も調へられており，分子の酸化電

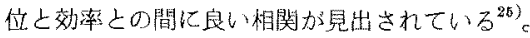
メロシアニンを用いた湿式北電池娄試みられている゙7?。 また，長鎖アルキル基老結合したメロシアニンの薄膜が， 中性溶液処理により長波長域に新して吸收带を生じ， それと同時に光電流が大稫に增加するととが見出され た ${ }^{39)}$ 。これは色素の会合体形成が光エネルギー变㷜儿有 利に働くこと在示しており，比合成系との関連で與味が 持たれる。

フタロシアニンを用いた研尙例卑多い。とくに，x形 フタロシアニンの樹脂分散膜についてはカナダのXerox 社のグループが桶力的な仕事を行なっている。この系は、 微弱光下では $6 \%$ という高いエネルギ一变換効率を示す が、光が強くなるとともに著しく効摔が咸少してしまう の加尔点であっだ)。しかしたの後，ZnOとのへテロ接 合や ${ }^{40}$ 湿式の系 ${ }^{38}$ を用いることで，との問題も改善さ れつつある。この方式は，色素，ポリマ一、溶媒という 了成分系在报うため，製造条件が複雑で，不明な点が多 く残されている。この点を究明するととにより，更に性 能が向上するととが期待される。例えば、筆者らは， $\alpha$ 形フタロシアニン分散膜を用いた光電池に施いて，バイ ンダーとして極性ポリマーを用いると効率が向上するこ とを胃出しだ'。

フタロシアニン蒸蓞膜と他の有機物質，例えばペリレ ン誘導体との接合在用いたものは，模擬太陽光下で1\% のエネルギー変換効率走した ${ }^{29)}$ 。フタロシアニンの中 心金属の効果が調へられ，メロシアニンの場合と阔樣， 酸化電位と効率との相関が示惨されている ${ }^{30)}$ 。フタロシ アニンを用いた太陽撆池についての詳細は他の総説を参 照されたい ${ }^{41)}$ 。

てれまで述へてきたものはすべて，有機物兵と電極と の界面における光起電力を利用している。乙れと原理的 に全く異なるおのとして，強誘電性ポリマー，ポリフッ 化ビニリデンの自発分極を利用した光電池が蚞討されて (1) ${ }^{42)}$ ?

\section{5.おわりに}

有機材料の魅力の一つは，そのバリエーションの豊か さにある亡言える。分子構造を合目的系統的に改変する ことにより，望ましい機能を発現させることが期待され てきた。しかし一方で, とのバリエーションの豊かさが 研究の進展を阻害していると屯考えられる。無機半導体 素子開登の初期においては，ゲルマ二ウムやシリコンだ けに照準を絞って，集中的な実験，理諭解析が扔てなわ れ，その結果，エレクトロニクスの飛躍的発展をるたら した。その過程では，基礎研究と応用研究上が密接に連 携して, 問題解決が行なわれたという ${ }^{43}$ 。一方, 何百万 
表 1 乾式有機太陽電池の実例

\begin{tabular}{|c|c|c|c|c|c|c|c|c|}
\hline 年 & 物 譬 $\mathrm{a}, \mathrm{b}$ ) & 製 法 & 電極 & $\begin{array}{c}\text { 光の種類，強度 } \\
\mathrm{mW}, \mathrm{d}) \\
\mathrm{mW} \mathrm{cm}^{-2}\end{array}$ & $\begin{array}{c}V_{\text {oc }} \\
V\end{array}$ & $\begin{array}{c}J_{\mathrm{sc}}^{\mathrm{e})} \\
\mu \mathrm{Acm}^{-2}\end{array}$ & $\eta$ & 女 献 \\
\hline 1973 & $\ddot{\gamma} ト \vec{\gamma} セ ン$ & 䉑 & $\begin{array}{l}\mathrm{Al} \\
\mathrm{Au}\end{array}$ & 白 色 炕 & 0.65 & $0.06 \%$ & $10^{-4}$ & 17) \\
\hline \multirow{2}{*}{1974} & \multirow{2}{*}{$\mathrm{MgPC}$} & \multirow{2}{*}{ 然 } & $\overline{\mathrm{Al}}$ & 白色光 & 0.9 & $0.09 \%$ & $10^{-8}$ & \multirow{2}{*}{ 18) } \\
\hline & & & $\mathrm{Ag}$ & $690 \mathrm{~mm}$ & - & - & 0.01 & \\
\hline 1975 & クロロフィル & 畕 & $\begin{array}{l}\mathrm{Cr} \\
\mathrm{Hg}\end{array}$ & $745 \mathrm{~nm}, 0.23^{*}$ & 0.32 & 0.98 & 0.05 & 5) \\
\hline 1975 & $\begin{array}{l}\text { ポリビニルカルパゾール } \\
(\text { トリニトロフルオレノン) }\end{array}$ & $\neq+x+$ & $\begin{array}{l}\mathrm{Au} \\
\mathrm{SnO}_{2} \\
\end{array}$ & $600 \mathrm{~nm}$ & - & - & $\sim 10^{-4}$ & 19) \\
\hline \multirow{2}{*}{1976} & \multirow{2}{*}{ ヒドロキシスクアリウム } & \multirow{2}{*}{$\begin{array}{l}\text { 蒸 } \\
\neq+x+1\end{array}$} & $\mathrm{Ga}$ & $\mathrm{AMO}, 0.14^{* *}$ & 0.45 & $0.25 \%$ & 0.1 & \multirow{2}{*}{ 20) } \\
\hline & & & $\mathrm{Pt}$ & AMO, $135^{* *}$ & - & - & 0.02 & \\
\hline 1977 & オクタエチルポルフィリン & 蒸䕎 & $\begin{array}{l}\mathrm{Al} \\
\mathrm{Ag}\end{array}$ & - & 0.4 & 0.003 & 0.1 & 21) \\
\hline 1978 & メロシアニン & 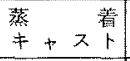 & $\begin{array}{l}\mathrm{Al} \\
\mathrm{Ag}\end{array}$ & AM $1,78^{* *}$ & 1.2 & 1800 & 0.7 & 22) \\
\hline 1978 & $2 \mathrm{nPc}$ & 著 & $\begin{array}{c}\operatorname{In} / \mathrm{Al} \\
\mathrm{Au}\end{array}$ & $633 \mathrm{~nm}, 0.19^{*}$ & 0.22 & 13 & 0.7 & 23) \\
\hline \multirow{2}{*}{1979} & $x-\mathrm{H}_{2} \mathrm{PC}$ & \multirow{2}{*}{ 分 散 } & $\mathrm{Al}$ & $670 \mathrm{~nm}, 0.006^{*}$ & 0.86 & 1.4 & 6.5 & \multirow{2}{*}{ 3) } \\
\hline & 一椙り酢酸ビ二ル & & $\mathrm{SnO}_{2}$ & 滢㘈太陽光， $8^{*}$ & - & - & 0.07 & \\
\hline 1979 & クロロフィル & 筆分子瞙 & $\begin{array}{l}\mathrm{Al} \\
\mathrm{Hg}\end{array}$ & 赤色光, $100^{* *}$ & 0.27 & 0.14 & $\begin{array}{c}0.04 \\
\text { (対吸妀光) }\end{array}$ & 7) \\
\hline 1980 & 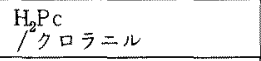 & スパッ夕ー & $\begin{array}{l}\mathrm{Al} \\
\mathrm{Al}\end{array}$ & $633 \mathrm{~nm}, 02^{*}$ & 0.47 & 9.5 & 0.45 & 24) \\
\hline 1981 & 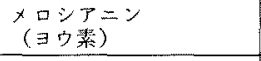 & 晴 & $\begin{array}{l}\mathrm{Al} \\
\mathrm{Au} \\
\end{array}$ & AM2, $45^{* *}$ & 0.7 & - & 0.18 & 25) \\
\hline 1981 & メロシアニン & 箸 & $\begin{array}{l}\mathrm{ZnO} \\
\mathrm{Ag}\end{array}$ & 白色光， $70^{* *}$ & 0.45 & 800 & 0.15 & 26) \\
\hline 1981 & クロロフィル & 琹 槛 膜 & $\begin{array}{l}\mathrm{Al} \\
\mathrm{Ag}\end{array}$ & $678 \mathrm{~nm}, 0.03^{*}$ & - & - & 0.038 & 8) \\
\hline 1981 & ボリアセチレン & 重 合 膜 & $\begin{array}{l}\mathrm{Al} \\
\mathrm{Au}\end{array}$ & 白色光, $2^{*}$ & 0.4 & 40 & 0.2 & 27) \\
\hline \multirow{2}{*}{1981} & \multirow{2}{*}{ ボリアセチレン } & \multirow{2}{*}{ 重 合 膜 } & \multirow[t]{2}{*}{$\mathrm{Al}$} & AM2, $0.21^{*}$ & 0.3 & 6 & 0.3 & \multirow{2}{*}{ 28) } \\
\hline & & & & $\mathrm{AM} 2,4.2^{*}$ & 0.31 & 63 & 0.1 & \\
\hline 1981 & 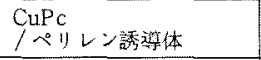 & 著 & $\begin{array}{l}\text { 市サ } \\
\mathrm{Ag}\end{array}$ & $\mathrm{AM} 2,75^{* *}$ & 0.44 & 3000 & 1.0 & 29) \\
\hline 1981 & 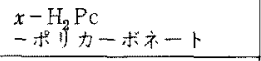 & 散 & $\begin{array}{l}\text { In } \\
\text { 卒 }\end{array}$ & AM0, $1^{*}$ & 0.4 & 179 & 2.4 & 4) \\
\hline 1981 & $\mathrm{MgPc}$ & 着 & $\begin{array}{c}\mathrm{In} / \mathrm{Al} \\
\mathrm{Au}\end{array}$ & 模擬太踢光， $100^{* *}$ & 0.334 & 230 & 0.019 & 30) \\
\hline \multirow{2}{*}{1981} & $\alpha-\mathrm{H}_{2} \mathrm{PC}$ & \multirow{2}{*}{ 分 散 } & \multirow{2}{*}{$\begin{array}{c}\mathrm{Al} \\
\mathrm{In}_{2} \mathrm{O}_{3} \\
\end{array}$} & $617 \mathrm{~nm}, 0.003^{*}$ & 0.62 & 0.78 & 5.5 & \multirow{2}{*}{ 31) } \\
\hline & 一ポリフッ化ビニリデン & & & $617 \mathrm{~nm}, 0.1^{*}$ & 0.92 & 8.7 & 1.4 & \\
\hline 1982 & 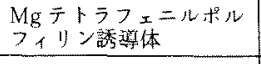 & 著 & $\begin{array}{l}\mathrm{Al} \\
\mathrm{Ag}\end{array}$ & $440 \mathrm{~nm}, \begin{array}{l}0.005 \\
-0.008 \\
\end{array}$ & - & - & 0.12 & 32) \\
\hline 1982 & 輠西活性 $\mathrm{AlPC}$ & 濐 & $\begin{array}{l}\mathrm{Al} \\
\mathrm{Ag}\end{array}$ & $638 \mathrm{~nm}, \quad 0.004^{*}$ & - & - & 0.72 & 6) \\
\hline 1982 & $\begin{array}{l}\text { ×ロシアニン } \\
\text { (塩菜) }\end{array}$ & 着 & $\begin{array}{l}\mathrm{Al} \\
\mathrm{Au}\end{array}$ & $\mathrm{AM} 2,90^{* *}$ & 0.73 & 1000 & 0.31 & 33) \\
\hline 1983 & $\begin{array}{l}\text { CIAICIPc } \\
/ \mathrm{CdS}\end{array}$ & 著 & $\begin{array}{l}\text { ネサ } \\
\mathrm{Au} \\
\end{array}$ & AM2, $75^{* *}$ & 0.69 & 890 & 0.22 & 34) \\
\hline 1983 & $\mathrm{PbPc}$ & 著 & $\begin{array}{l}\text { Al } \\
\text { I TO }\end{array}$ & 白色光，100** & 0.3 & 34 & 0.002 & 14) \\
\hline
\end{tabular}

(注) ${ }^{\mathrm{a})} \mathrm{Pc}$ はフタロシアニンの略

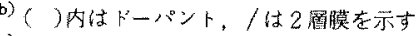

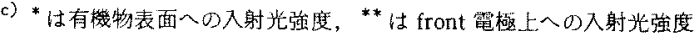

d) AMは Air Mass の略で，太陽光か通過する大気の瞌を意味し，てれによって太陽光のスペクトル分布を市す。

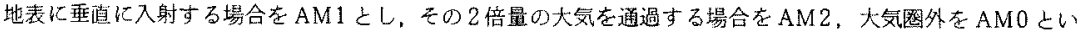
うように表わす。

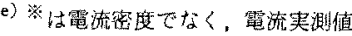


表 2 湿式有機太陽電池の突例

\begin{tabular}{|c|c|c|c|c|c|c|c|c|c|}
\hline 管 & 作 用 極 & 製 法 & 対 極 & 䤒化選元洞 & $\begin{array}{c}\text { 光の種類, 強度 } \\
\mathrm{mW} \mathrm{cm}^{-2}\end{array}$ & $V_{\mathrm{oc}}$ & $\begin{array}{c}J_{\mathrm{sc}} \\
\mu \mathrm{Acm}^{-2}\end{array}$ & $\eta$ & 文 献 \\
\hline 1978 & $\mathrm{Pt} / \mathrm{AlClPC}$ & 蒸 美 & $\begin{array}{c}\mathrm{Ag} / \mathrm{AgCl} \\
\text { (?) }\end{array}$ & $\mathrm{O}_{2}$ & 白色淡， 100 & - & 20 & - & 35) \\
\hline 1980 & $\mathrm{Al} / \mathrm{Mg}$ ポルつィン & 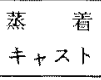 & Pt & $\begin{array}{l}\mathrm{Fe}(\mathrm{CN})_{8}^{3-} \\
\mathrm{Fe}(\mathrm{CN})_{6}^{4-}\end{array}$ & $445 \mathrm{~nm}$ & 1.0 & - & 1 & 36) \\
\hline 1980 & 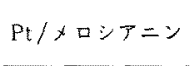 & 蒸 & $\mathrm{Pt}$ & $\begin{array}{l}\text { メチルビオロ } \\
\text { ゲン }\end{array}$ & 白色光，37 & 0.74 & 4.4 & - & 37) \\
\hline 1982 & $\mathrm{SnO}_{2} / x-\mathrm{H}_{2} \mathrm{PC}$ & 分 & $\begin{array}{c}\mathrm{In} / \mathrm{Pb} / \mathrm{Hg} \\
\text { 合 金 }\end{array}$ & ヘンゾキイン & AM 2, 75 & 0.21 & 1800 & - & 38) \\
\hline
\end{tabular}

種と屯言扣れる有機化合物の中から，「シリコン」に相 当するもの見つけ出すの恎難の技である。その上う なあのがあるという保証李ないるまた、メロシアニンや x形フタロシアニンが何故優れているのか，必ずし屯明 ら加にっているとは吾い難い。汃くのごとく，との分 野に招いては，対象を絞ったintensiveな゙研究が、やり にくい。乙のととは，一つの技術を完成するために，長 大な時間と労力を要するととを意味している。

最近 5〜6年間に，有機太陽電池の效率は飛躍的に向 上したが，実用レベルとの差はまだ大きい。これるでは， 効率向上しいう面だけが强調されてきたが，今後は基磷

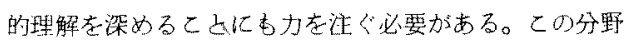
の問題点として，他人の仕事の追試に战功したという例 が少なく，各グループの成果が有機的に連関しにくい上 いうことがある。こ扎は，基本的諸問題が，研究遂行上 お，また発表の場でも看過されがちであるため上思われ る。先に述べた，有機物における Schottkyバリアーモ デルの㚣当性の問題はその一例である。また，蒸着膜か よく詡いられるにもかかわらず，有機蒸萫膜の形成機構 についてはわかっていないととが多い。この問題は、薄 膜のモルフォロジーに密接につながり，更に電子やホー ルの挙動に大きな影響を与えるはずのものである。この 分野に携わった研究者なら，一度はピンホールに悩まさ れた経験を持つものと思われるが，てれる薄膜形成機構 に関連している。

近年, 導電性高分子材料や分子電子デバイスなよ゙，有 機物を電子材料として用いるための研究が盛んになって いる。有機太陽電池を、この流れに咲いたあだ花に終わ らせないためには，上に述べたような，地味ではあるが 着実な研究を蓄皘するとよ汃何より大切である。

\section{文献}

1) F. Gutmann and L. E. Lyons, "Organic Semiconductors", Wiley, New York, Chap. 8, p. 516 (1967)
2) G. A. Chamberlain, Solar Cells, 8, 47 (1983)

3) R. O. Loutfy and J.H. Sharp, J. Chem. Phys., $71,1211(1979)$

4) R. O. Loutfy, J. H. Sharp, C. K. Hsiao and R. Ho, J. Appl. Phys, 52, 5218 (1981)

5) C.W. Tang and A. C. Albrecht, Nature, 254, 507 (1975)

6) J.-P. Dodelet, H.-P. Pommier and M. Ringuet, J. Appl. Phys., 53, 4270 (1982)

7) A. F. Janzen and J. R. Bolton, J. Am. Chem. Soc., 101, 6342 (1979)

8) M. F. Lawrence, J.-P. Dodelet and M. Ringuet, Photochem. Photobiol, 34, 393 (1981)

9) M. Saito, M. Sugi, T. Fukui and S. Iizima, Thin Solid Films, 100, 117 (1983)

10）南信次，佐々木筧治，高分子諭文集，40，211 (1983)

11) A. Fujishima and K. Honda, Nature, 238, 37 (1972)

12) H. Gerischer and F. Willig, Top. Current Chem., 61, 31 (1976)

13) 植村泰忠，菊池 誠，「半導体の理論上地用 (上)]. 裳華房, p. 285 (1960)

14) S. Kanayama, M. Hiroi, N. Okuyama and H. Yasunaga, Jpn. J. Appl. Phys., 22, 348(1983)

15) M. Martin, J.-J. André and J. Simon, J. Appl. Phys., 54, 2792 (1983)

16) A. Rose, "Concepts in Photoconductivity and Allied Problems", Interscience, New York, p. 38 (1963)

17) A. K. Ghosh and T. Feng, J. Appl. Phys., 44, 2781 (1973)

18) A. K. Ghosh, D. L. Morel, T. Feng, R. F. Shaw and C. A. Rowe, Jr., J. Appl. Phys., 45, 230 (1974)

19) P. J. Reucroft, K. Takahashi and H. Ullal, J. Appl. Phys., 46, 5218 (1975)

20) V. Y. Merritt and H. J. Hovel, Appl, Phys. Lett., 29, 414 (1976)

21) F. J. Kampas and M. Gouterman, J. Phys. Chem. 81, 690 (1977)

22) D. L. Morel, A. K. Ghosh, T. Feng, E. L. Stogryn, P. E. Purwin, R. F. Shaw and C. 
Fishman, Appl. Phys. Lett., 32, 495 (1978)

23) F.-R. Fan and L.R. Faulkner, J. Chem. Phys., 69, 3334, 3341 (1978)

24) V. A. Ilatovskii, I. B. Dmitriev and G. G. Komissarov, Russ. J. Phys. Chem., 54, 696 (1980)

25) G. A. Chamberlain, P. J. Cooney and S. Dennison, Nature, 289, 45 (1981)

26) T. Moriizumi and K. Kudo, Appl. Phys. Lett., 38, 85 (1981)

27) J. Tsukamoto, H. Ohigashi, K. Matsumura and A. Takahashi, Jpn. J. Appl. Phys., 20, L127 (1981)

28) B. R. Weinberger, S. C. Gau and Z. Kiss, Appl. Phys. Lett., 38, 555 (1981)

29) C. W. Tang, US Patent, 4,281,053 (1981)

30) M. Martin, J.-J. Andre and J. Simon, Nouv. J. Chim., 5, 485 (1981)

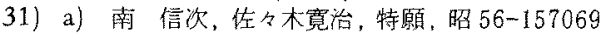
b) N. Minami, K. Sasaki and K. Tsuda, J. Appl. Phys, in press

32) K. Yamashita, N. Kihara, H. Shimidzu and H. Suzuki, Photochem. Photobiol., 35, 1 (1982)
33) G. A. Chamberlain, J. Appl. Phys, 53, 6262 (1982)

34) A.-M. Hor, R. O. Loutfy and C.-K, Hsiao, Appl. Phys. Lett., 42, 165 (1983)

35) V. A. Ilatovskii, I. B. Dmitriev and G. G. Komissarov, Russ. J. Phys. Chem. 52, 1469 (1978)

36) F. J. Kampas, K. Yamashita and J. Fajer, Nature, 284, 40 (1980)

37) G. A. Chamberlain and R. E. Malpas, Faraday Discuss. Chem. Soc., 70, 299 (1980)

38) R. O. Loutfy and L. F. McIntyre, Solar Energy Mater., 6, 467 (1982)

39) F. Mizutani, S. Iijima, K. Sasaki and Y. Shimura, Ber. Bunsenges. Phys. Chem., 86, 907 (1982)

40) R. O. Loutfy, Y.-H. Shing and D. K. Murti, Solar Cells, 5, 331 (1982)

41) 南 信次，電子写真，印刷中

42) H. Sasabe, T. Nakayama, K. Kumazawa, S. Miyata and E. Fukada, Polymer J., 13, 967 (1981)

43) 菊池誠，応用物理，51，1338(1982)

(昭和 58 年 8 月 17 日受理)

\section{繊維学会}

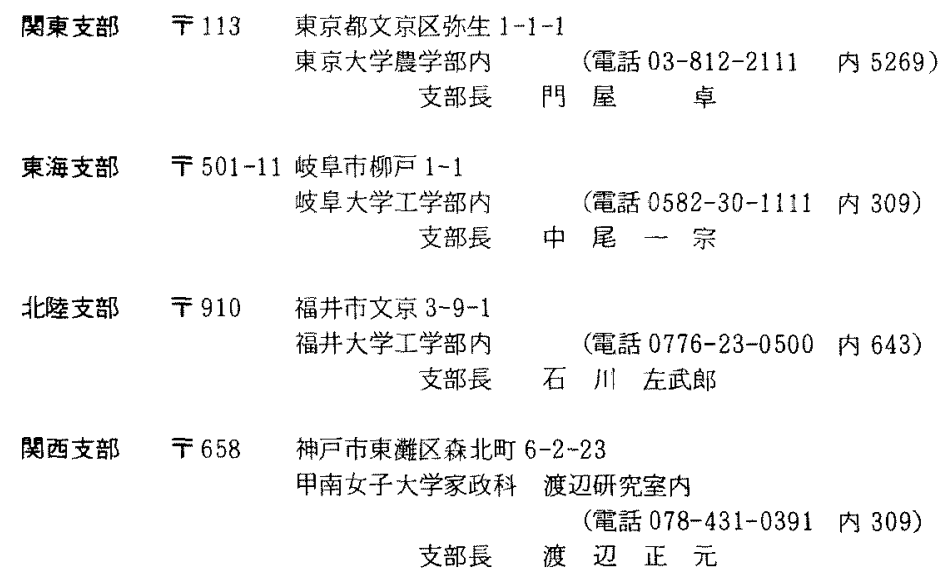

